\title{
Pelvic Kidney
}

National Cancer Institute

\section{Source}

National Cancer Institute. Pelvic Kidney. NCI Thesaurus. Code C99006.

A cong enital abnormality characterized by the failure of the kidney to ascend to its normal position and it remains in the pelvis. 